【論 文】

UDC : 72.03(52): 69.007.2
日本建築学会計画系論文報告集 第 431 号・1992年 1 月 Journal of Archit. Plann. Environ. Engng, AIJ, No. 431, Jan., 1992

\title{
創成期の東福寺とその大工たち \\ TOHFUKUJI-TEMPLE AND CARPENTRY BUILDERS \\ IN ITS FOUNDING TIME
}

永井規 男*

Norio NAGAI

\begin{abstract}
Tohfuku-zen-ji-temple had deep relation to the establishment of Zen style in Japanese architecture.

In this paper, I discuss the process of adopting Zen style in the buildings of this temple in the relation of the matters of their carpentry builders. Conclusions are as follows.

1. Tofukuji-temple, founded in 1239, had converted to zen-proper institute in the moment of the construction of hattou (lecture hall) in $1270 \mathrm{~s}$.

2. The establishment of Zen-style in this temple was paralell phenomenon to the biginning of the succession of Daiku-shiki by one family using a letter "hiro" in their naming.

3. Probably, the using of zen-style in this temple, was pioneered by builder Suehiro and accomplished by Hirosada, conjectural founder of the daiku-shiki family of Tohfukuji.
\end{abstract}

Keywords : Tohfukü̈, Zen style, carpentry builders, early medieval ages 東福寺, 禅宗様, 番匠大工, 中世初期

1. はじめに

鎌倉時代になって禅宗寺院が建立されはじめ, わが国 の建築に決定的な影響を及ぼすことになった。では，そ うした禅宗寺院に固有の様式とされる禅宗様が, 禅宗寺 院において確立されたのは何時ごろか，またそれに関与 した建築工はどのような人たちであったのだろうか。こ れらは禅宗様の形成という問題のなかにおいて，きわめ て重要な位置を占めるものであろう”。とはいうものの, 史料の絶対的な欠如が，これらを論ずることをたいへん 困難なものにしている。しかし，この点をすこしでも明 らかにしておかなければ，禅宗様式やその技術に関する 諸問題をより深く論じることはできないと思われる。本 稿は，こうした問題意識にたって，わが国の初期禅宗寺 院における禅宗様式の形成とその建築工匠について考察 を試みようとするものである。もっとも，初期禅宗寺院 の工匠問題にまで及んで論じようとすれば, 史料の関係 上から，その対象は，ほとんど京都の東福寺に限られて しまうのである。そこに問題はのこるものの，しかし， 五山制度形成以前の京都禅宗寺院界における東福寺のも つ役割を考慮に入れると ${ }^{2)}$ ，それに関する考察は，東福 寺だけのことにとよ゙まらず，より一般性のもつものとし て受け入れられるであろう。
以下に述べるように，東福寺ははじめから禅宗寺院と して出発したわけではないし，またこの時期の東福寺工 匠史料というのも，かならずしも密度の高いものではな い。そこで東福寺が禅宗寺院化する過程を検証し，それ と対応してそこに登場する大工を，彼らの背景に可能な 限り踏み込み，それらの結果を総和するかたちで議論を すすめてみたい。

\section{2. 東福禅寺の形成に関する問題}

東福寺の創立に関しては，太田博太郎，杉山信三両氏 による研究があり どない。しかし，細部においてはなお論ずべき余地が若 干あるようである。

東福寺の創立に関してまず扱っておかなければならな いのは，九条道家の「惣処分」4) の問題である。「惣処分」 は，東福寺の創立期の建築状況を示すものと信じられて いるが，その内容，とくに東福寺の部分の内容は多くの 矛盾を含んでいる。そこでまず「制処分」をいかに見る ベきかの問題から入ろう。創立期の東福寺の建築に関し て信頼できる基礎的な史料としては,「軳処分」以外に「聖 一国師年譜 $\rfloor^{(5)}$ と「東福寺大工広定請文案 $\rfloor^{6}$ とがある。 仏殿造営にはじまる東福寺諸堂宇の造営経過とそれに関 
連する大工とをこの二つの史料を対比するかたちで下 に示す。

\begin{tabular}{|c|c|c|}
\hline 年次 & 聖一国師年譜 & 東福寺大工仏定請文案 \\
\hline 延応元 7.21 & 仏殿立柱 & $\begin{array}{l}\text { 果儃守人上ム正的又采 } \\
\text { 仏殿造営 }\end{array}$ \\
\hline 8.5 & 仏殿上棟 & 【大工物部為国】 \\
\hline 寛元 4 & 普門院建立 & \multirow{2}{*}{ 【末光】 } \\
\hline & 九条道家甍 & \\
\hline 建長 7.6.2 & 仏殿落慶 & \multirow{4}{*}{$\begin{array}{r}\text { 鐘楼·経蔵・廊下造営 } \\
\text { [大工本】 }\end{array}$} \\
\hline 正嘉 2 & 仏殿北嫏造営 & \\
\hline 正元元 & 東福方丈あり & \\
\hline 文永 5 & 常楽庵創立 & \\
\hline 文永 8 & $\begin{array}{l}\text { 法堂·祖堂·垌堂 } \\
\text { 造営 }\end{array}$ & \multirow[t]{3}{*}{$\begin{array}{r}\text { 法堂・祖師堂・檀那堂 } \\
\text { (大工束) }\end{array}$} \\
\hline 文永 10 & 法堂落慶 & \\
\hline 弘安 2 & 開山円爾辨円示寂 & \\
\hline \multirow{3}{*}{\multicolumn{2}{|c|}{3 世無関普門の代 }} & 温室造営 \\
\hline & & 【大工定吉】 \\
\hline & & \\
\hline \multirow{2}{*}{\multicolumn{2}{|c|}{5 世山㕜恵雲代 (-1301 寂) }} & 中尊御光改修，諸堂作 \\
\hline & & 事, 【大工広定】 \\
\hline
\end{tabular}

このように円爾までの時代の建築造営経過に関して， この二つの史料はほぼ同様の，相互に矛盾しない事柄を 示している。「東福寺大工広定請文案」は 14 世紀の始め ころ大工相論にからんで作られ, 東福寺大工家が襲蔵し ていたもの。「聖一国師年譜」は14 世紀前半の人である 岐陽方秀が編集したもので，いずれも同時代史料とはい えないが，その内容に虚偽や作為を施さねばならないよ うな性格のものでもない。この二つの史料が，その内容 において，両者がほぼ一致し，とくに矛盾するところが ないことは，上の建築造営経過が事実であることを，ま た物語るといえよう。

「惣処分」は建長 $2(1250)$. 年 11 月に，九条道家が死 を前にして遺した道家関係の諸寺院の堂宇等の目録，及 び寺領・家領の処分案である。文書袖書によると法印仁 基の執筆とあって道家の直筆によるものではない。さて， 「惣処分」に記された東福寺は，仏殿・法堂・二階楼門・ 僧堂以下，禅宗寺院としてあるべき諸堂宇が完備したも のとなっている。ところが，「制処分」の東福寺の項の 末尾に記された道家の述懐は，「数箇の堂宇を建立する なり」とあると同時に，また「但し，未作事のもの甚だ 多し」ともあって，堂宇目録そのものの内容とは明らか に矛盾している。上記の二史料と照らしても，「惣処分」 に記す鐘楼・経蔵・法堂・温室 (浴院) などは道家没後 の造営であることが明らかである。以上のことからして も，「惣処分」に記された東福寺の堂宇目録をもって, ただちに建長 2 年時の状況を表すものとすることはでき ない。もちろん，この東福寺堂宇目録は，まだ建ってい ないものを含めて, 完成した時のあるべき姿を予想して 書かれたという解积もできよう。しかし，この堂宇目録
を子細にみると，五重塔婆だけは「件塔は東の岸上に建 立す可し」と明確に将来建てるべきものとされているも のの, 法堂などは「建立す可し」という書き方はされて いないのである。こうしてみると「牢処分」の東福寺の 堂宇目録は，建長 2 年以降のある時点における，ほぼ完 備した状態を書いたものを, 道家が作成した当初の処分 案の中に嵌入したものと考えられるのである”。

そうなると, 創立期東福寺の道家時代の堂宇の姿を, 「惣処分」を通して見，そこから完成された禅寺が道家 の生前にすでにあったとしてしまうと，事実を見誤るこ とになろう。そこで，あらためて，禅宗寺院としての東 福寺の姿がいかにして，いつごろ形成されていったかが 検討されねばならなくなる。

[道家の造寺意図]杉山信三氏が指摘されたように ${ }^{8)}$, 「東福寺」の仏殿は，はじめは最勝金剛院の御堂として 意図されたのであった。すなわちそれは禅宗寺院として の仏殿ではなかったのである。この仏殿造立の動機は明 らかではないが, 天福元（1233）年の藻壁門院（後堀川 天皇中宮，四条天皇母），嘉禎元（1235）年の摄政教実 と続いた，九条家の将来にとって重要な役割を担う筈の 子供たちの死という不幸に遭遇したことが，大きく作用 したことは推測にかたくない。それが，延応元（1239） 年の道家自身の罹病と比良山神託という体験" を経て, 最勝金剛院を拡大するという最初の意図が転じて，新規 の寺院の開設へと移っていったものと推測される。東福 寺の名称もこの転換を機に始められたと思われる ${ }^{10)}$ 。し かし，その転換はただちに禅宗寺院を志向したものでは なかった。それは，寛元 4 （1246）年に春日社に納めた

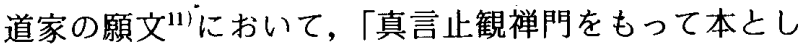
て」造寺していると述べていることから推測できる。円 爾辨円を住持に迎えたのは，禅宗をその一部として加え ようとしたこともあろうが，むしろ人宋僧である円爾の 下で, 新しい風儀の造寺が行なわれることを期待したか らであろう。そのことは道家が「制処分」のなかで，造 寺の方針について「偏に天答晨旦叢林開堂の風俗を模す」 とか「宋朝の風俗」と述べていることからも推測できる。 おそらく，道家は，最後まで，東福寺を禅宗寺院として 考えたことはなかったのである。それは道家本人が遺書 である「制処分」において，「真言止観宗門を以て専宗 となす」と述べていることからも明らかであろう。

[円爾による禅寺化] 円爾が道家とはじめて出会ったの は, 寛元元 $(1243)$ 年 2 月, 月輪別墅においてで, 同 4 年には東福寺の北の普門院を与えられている12)。しかし， 円爾が本当に東福寺に腰を落ち着けたのは，住庵として の常楽庆が創営された文永 5 （1268）年ころであろう。 このころから東福寺は, 禅僧としての円爾が統率する寺 院，すなわち禅宗寺院としての性格を明確化してゆくの である。そのことは， 3 年後の文永 $8(1271)$ 年から開 
始された法堂と祖堂および跼堂の建設がよく物語ってい る。仏殿落成後, 16 年間も禅宗寺院によって最重要の 法堂は未建のままであった。この時間差のことは,これ まで見過ごされているが，一考すべき問題ではあろう。 これについては着手が遅れただけという解釈も可能であ る。しかし「惣処分」の堂宇目録には記載のない祖堂や 祠堂の建築が, 法堂建設と同時に行なわれていることに 注意しなければならない。従来はこの祖堂と柌堂は法堂 に付属させたものとの理解が普通であるが ${ }^{131}$ ，「建長寺 指図」に見られるように，仏殿の両側に付くものとして 新たに付属させたという可能性もないではない。いずれ にせよこれから明らかになることは, 道家時代の建長 7 （1255）年に落成した仏殿には, 祖堂と袔堂は付属して いなかったということである。すくなくとも，南宋五山 式の伽藍構成では必須の, したがって禅宗様化のひとつ の指標となる祖堂と雟堂も, 法堂と同様に道家の計画に はなかった可能性がおおきい。このように考えると, 法 堂の建設は, 単なる着工の遅れというものではなく, 東 福寺の禅宗寺院としての方向づけが確定した結果とし て，はじめて企画された工事だったのだと理解できるの である。

この推測は東福寺の仏殿と法堂の配置関係の不自然 さ,すなわち両堂が異常に接近しすぎている ${ }^{14)}$ 事実から 裏付けできよう。この異様な配置は, 最初の配置計画に 法堂が念頭に入っていなかっだこと，いいかえれば道家 の造寺計画は楼門と仏殿だけを中核としたことに起因し たと考えられる。もし当初から法堂建設が計画されてい たとしたらここのうな異様な配直にはならなかった筈 である。

ともかく法堂は文永 10 年には落成し，ここに東福寺 の禅宗寺院としての体裁がはじめて備わるのである。さ らにその 2 年後の建治元 $(1275)$ 年 9 月には, 道家の三 男一条実経（1223～84）が，子家経はじめ諸官從を引き 連れて, 東福寺に入り, 円爾に請うて上堂, 入室札を行 なっている ${ }^{15)}$ 。このことは檀主である一条家が，名実之 もに東福寺が禅宗寺院であることを世間に告知したもの でありここにおいて東福寺は禅宗寺院として認知され たといえるのである。弘安 3 (1280) 年 6 月の, 円爾に よる東福寺規式 ${ }^{16)}$ には「仏鑑禪師叢林規式をもって一期 (一生) 之を遵行し, 永く退転あるべからず」とあって, そこでは天台真言色は払拭されてしまっている。

\section{3. 造営の実務者たち}

禅宗寺院として確立した東福寺の造営運営上の実務 は, 14 世紀の諸史料が示すように，修造司を常置執務 者とし，造営奉行を中心にする知事僧たちによる臨時の 機構において行われた ${ }^{17)}$ 。しかし，そうした禅院内部の 造営機構が東福寺に当初から備わっていたとは考えがた
い。弘長三年 (1263) の「三聖寺規式」, 弘安三年 (1280) の「東福寺壁書」, 「普門院常楽庵条々規式」18)などから は，そうした機構の存在は窥いがたいのである。では, 創立期においては，造営の実務は誰が担ったのであろう か。残念ながら，そのことを直接示す史料は見出せない。 しかしこの問題は, 後に扱う工匠の問題にも重要な意味 をもつので, 推定の域を出るものでないとしても, 及ぶ かぎり論及しておきたい。

道家が祖父兼実から受継いだ最勝金剛院は, 堂廊之御 所を付属させた本堂, 塔婆, 鐘楼, 僧房 (護摩堂) とい う構成をもつものであった年。その規模は明らかでない が,堂廊や御所が付属しているというところからすると, 本堂はそれほよ゙のものとも思えない。おそらく常住する 僧数もすくなく，それ自体としての修造組織をもたな かったろう。となると, 五丈の高さをもつ大釈迦如来坐 像を本尊亡する仏殿の造営は, それまでの最勝金剛院か らの質量ともどもの脱皮を意味するものであって，そこ ではその造営のための造営組織が設定されたに違いない のである。

残念ながら，東福寺関係の史料にはこれに関すること は見出せない。そこで，類例として摄関家の重要な氏寺 である法成寺や平等院の同時代の場合はどうであったか を調べそこから類推することにしたい。

まず法成寺であるが，ここには寺務を司る別当がおか れ，その下に修理別当，執行などがいて造営や修理に当 たるのが建前であり，それに付属する修理所や造営料所 が常置されていた ${ }^{20)}$ 。文治 $2(1186)$ 年, 同寺の修理に つき，氏長者藤原兼実は，修理別当聖顕と執行泰覚の両 人が分担して奉行すべきことを命じ，金堂を泰覚が無量 寿院を聖顕が担当することになったが21)，これなどこの 原則にしたがった処置なのであった。しかし，この両人 が修理奉行としてよ゙れほよ゙の実効をあげたかは明らかで なく，13世紀になると寺務による修造には殆ど期待で きないのが実態であった。天福元 (1233) 年, 金堂の北 にたつ北御堂が顛倒したのは寺務の急慢によるもので

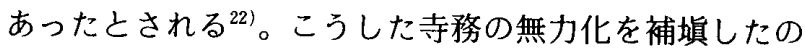
は，主として長者家の家司たちであった。文治 5 (1189) 年に大風で同寺が大破したとき, 兼実は家司高階資泰に その修理のことを命じ, 葉室宗頼をその奉行とし, 行事 侍等に破損状況を実検させている ${ }^{23)}$ 。寛喜 $2(1230)$ 年, 橘知宣は奉行として短期間に材木を集めて法成寺の修理 を行ない，宮廷で評判になった ${ }^{24)}$ 。貞永元 (1232) 年に 西面八足門が転倒したときは，下家司である左吏生康職 がその実地検分をおこなっている ${ }^{25)}$ 。最勝金剛院仏殿造 営の 5 年後の寛元 4 (1246) 年には; 法成寺之平等院の 両寺の修理が氏長者一条実経を願主として行なわれた が, 法成寺の事始では, 家司座がもうけられていて, 一 条家の家政機関がその実務の一部を担当していることが 
推定できる。この修理に際しては寺領が修理料に充てら れ，家司と考えられる行範がその沙汰をした。この事始 では木工二座，檜皮工，壁工等が出仕しているが，これ らは寺に所属する工匠たちであろう ${ }^{26)}$ 。この場合は，寺 家の修理機構と長者家の家政機関中の適任者がその任に 当たっているのであるが，その年末に造営実務に怠慢で あったとして執行泰舜は罷免され，親覚法眼に交替して いる。実際には寺務側はほとんど造営実務能力を喪失し てしまっていたよいってよい。

平等院の場合も執行が修理実務を担当していた。建治 元 $(1275)$ 年, 平等院執行範誉が寺の修理を命じられて いる27。しかし修理の実務に関しては, 執行より家司の 方が多く登場する。文暦元 (1234) 年の阿弥陀堂の修理 は九条道家の家司中原行兼の沙汰として行なわれたこと が知られている ${ }^{28)}$ 。一条実経の時代の寛元 4 年の修理で は, 葉室定嗣が修造奉行を辞退し，藤原高俊が任命され ている ${ }^{29)}$ が，彼らはともに実経の家司であった。

以上のような法成寺, 平等院の事例からすると, 最勝 金剛院の新仏殿から東福寺の創営にいたる造営の場合に も，氏長者家である九条家の家司が参画した可能性が高 いことが認められよう。その候補者として挙げられるの は中原行範と慶政上人である。

[中原行範] 寛元 2（1244）年秋に, 上野国長楽寺に師 栄朝を訪問する円爾を, 道家の命をうけて護衛同行した 備中守行範という人物がいる ${ }^{30 !}$ 。ところで，上述の寛元 4 (1246) 年の一条実経による法成寺修理の沙汰人であっ たのも行範という人であった。この人は同年の 4 月にも， 一条実経家の御神祭に際し, 御所艮方に建てる神殿を造 進している ${ }^{311}$ 。道家と実経が父子の間柄にあることから すると，備中守行範と後者の行範とは同一人物とみてよ いであろう。その人物像は，九条道家の日記『玉藥』に おいて若干明らかにすることができる。まづ，嘉禎 3 （1237）年 4 月 16 日条に，賀茂祭見物用の七間一面の 檜皮葺御栈敷の営作担当者として「目代左大夫尉行範」 が現れる。嘉禎 4 年正月 9 日条では西園寺公経の使者と して道家に会い，行範がその実務を担当したらしい䦥院 修理の件について述べている。同年 2 月 13 日条では, 道家の孫娘の五十日の祝に納殿預として現れ, 同年 4 月 10 日条では道家子の福王丸の仁和寺入寺の行列に「検 非違使 五位尉中原行範」として参仕している。以上の ことから, 行範は中原氏で, 検非違使を本務とする官吏 であること, 九条道家と一条実経の父子に, また西園寺 公経に家司として仕えていたことが知られる。中原行範 が，とくに建築経営の実務面に長じた人物であったこと は, 上述の僅かな史料からだけでも充分に推察できると ころであろう。

行範が中原氏だとなると, 上述の平等院阿弥陀堂修理 の沙汰人中原行兼のことが見過せなくなる。行兼は本務
を検非違使とする官吏であるが，また「亜相（西園寺公 経) 專一の者なり」といわれた西園寺公経の腹心の家司 であった。九条道家が西園寺公経の娘倫子と結婚すると， 道家の用も務めている。貞永元 (1232) 年, 高山寺の明 恵上人が最期を迎えたとき, 公経の使者として明恵を見

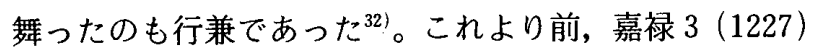
年に覚厳法眼の沙汰のもとに高山寺に三重塔が建立され たとき, 公経が中心となってその本尊と脇仏の五尊像を 造るが, 行兼も脇仏のひとつの文殊師利菩薩像を定慶に 造らせている ${ }^{33)}$ 。

行範とこの行兼とは, 官歴や名前の類似性から親子と 推定できる。行兼も建築経営の能力をもった人物であっ たから, 行範の建築経営の能力は親譲りのものなので あった。もし, 九条家の家司たちの中から, 新仏殿の造 営を担当できるであろう家司を求めるとしたら，この行 兼と行範が最適候補者として浮かび上がるのである。そ して円爾との関わりからいって，東福寺時代の造営には 行範が参与したと見たいところである。

〔慶政上人〕 円爾その人も勧進上人的な側面をもって造 営事業に活躍した人だった が，しかし，前述した経緯 からみて，円爾が創成期の造営事業に関与できたとは考 えられない。だが, 勧進上人であって, 東福寺の造営に 関与しえた可能性が高い人がいる。それは願主である道 家と強い踒がりをもっていた慶政上人である。慶政は先 述の比良山託宣に介在し, 道家による最勝光院から東福 寺への拡大転換に一役かったと推定される人物である。 慶政は房号を証月房といい, 園城寺において修学した僧 で, 文治 5 （1189）年に生まれ，文永 5 （1268）年 10 月 に 80 歳で入寂している ${ }^{35)}$ 。出自は明らかでないが堀池 春峰氏は九条道家の兄に当たる人と推定されており ${ }^{36)}$, 事実九条家との関係は密接なものがあった。松尾に法華 山寺を開き, 建歴 3 (1214) 年ころに渡宋, 建保 7 (1219) 年以前に帰朝している。法隆寺東院の舎利殿絵殿修理の 願主は慶政上人之され，建保 7 年から嘉禎 3 (1237) 年 にかけての間, 断続的ではあるが九条家の援助のもとに 願主となって法隆寺東院の諸堂修理に大きな功績をのこ した ${ }^{37)}$ 。くだっては, 東福寺の仏殿造営が行われていた ころ, 道家の外孫にあたる四条上皇の清涼殿を独力で三 井寺興乗院に移築していて ${ }^{38)}$ ，ここでも道家との深い繫 がりが認められる。このような建築経営に堪能で, 宋様 に関する知識もあったはずの慶政が, 道家の東福寺創営 に関わらなかったとは考えがたい。慶政も道家の家司的 存在と考えることができ，その意味では中原行範と同列 におくことができよう。

〔寺内造営機構〕では, 九条家という檀主側からはなれ て, 東福寺としての独自の造営組織はいつごろから存在 したのだろうか。そうした機構の存在を伺わせる「修造 司」なる役職は, 貞和 $2(1346)$ 年の大工左衛門大夫弘 
光への畠三段の給分を知行せしめた東福寺役者連署状に

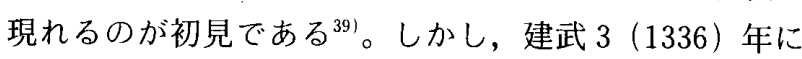
淡路国都志郷領家職が東福寺造営料として東福寺長老に 与えられ ${ }^{401}$, 建武 5 年 7 月にはその地頭分が東福寺侍者 慧料から大工左衛門大夫に与えられている(11)ら，建武 ころには，造営にかんする東福寺側の主体性は確立して いたと見られる。したがって，その主体性の檀主側から 東福寺側への移行は，これよりは早い時期に，お之らく は13 世紀末から 14 世紀始めのころになされたと推定し てよいであろう。

\section{4. 創立期の番匠大エたち}

「東福寺大工広定請文案」は，東福寺創成期の番匠大 工たちに関する唯一の史料であるが，その史料内容には おのずと限りがある。したがって，議論を深めるために， この史料に現われる番匠大工たちを，その周辺関係を含 めて検討してゆきたい。さて，「請文案」に現われる番 匠大工たちは，つぎのような四期にグループ分けするこ とができる。すなわち，【第一期〕物部為国と末光，〔第 二期〕末広，〔第三期〕定国，定吉，広定，〔第四期〕広 定以降，である。

[第一期］物部為国亡末光 $1230 \sim 40$ 年代

物部為国「請文案」は，東福寺仏殿を造営した大工 を物部為国とする。このことについて広定は「其の隠れ なし」と述べているので，為国が関わったことは間違い のない事実であろう。

物部為国は, 高野山奥之院拝殿の造営記録に ${ }^{42)}$, 伊勢 権大夫とされ，鎌倉初期の東大寺再建工事において，桜 嶋国宗とともに棟梁的な役割を果たした番匠大工伊勢権 守物部為里亡系譜的に繫がりのある大工と考えられてい る ${ }^{43 !}$ 。

東福寺仏殿以外にかれが関わったものとして，(1)高野 山奥之院拝殿 (1223) の造替, (2)宇治平等院中堂の修理, (3)東寺での造営，の三つが今までに知られている。

(1) 高野山奥院拝殿の運営 ${ }^{44}$ 'は, 奥院择殿が創立されて 以来五度目のものであるが,「古御詳殿ノ礎石小故, 今 度八以二大ナル石き_而可し為し礎也。」と記され，礎石 から新しくした新築工事であった。貞応 2（1223）年の 正月に着工して 4 月 20 日に完成している。造営の願主

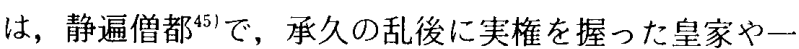
部の貴族たちによって支援された。九条道家は表向きこ の造営には姿を現していないが, 貞応元年十月に道家の 祖父兼実の兄松殿禅定基房が 80 歳を越えた老齢をおし て基家らとともに二度目の参詣を遂げて出家しているこ 亡が注目される。基家は道家の弟で，静遍僧都は基家の 妻の兄弟である。こうしてみると，この造営には，表に 出ないものの, その背後には九条家一門の援助があった と考えられる。
(2) 平等院鳳凰堂の修理は，文暦元年から 2 年 (123435ににかけて行われた。この修理に関する史料は，明治 36 年から 40 年にかけて実施された，鳳凰堂の修理の際 に発見された外陣柱方立の小穴の中の墨書(6) だけであ る。

文暦元年霜月廿九日, 為玉饰御庄預所口壱岐守中原朝臣行兼 之沙汰，被直此御堂，同二年三月十五日，重被直柱出入，雑 掌沙門定心, 大工伊勢大夫物部為国 (「大日本古文書】による) この修理の施主は氏長者である九条道家である。しか し，道家は日記『玉藥』にこの修理のことを記していな いから，とくに重要な修理事業とはみなされていなかっ たようである。

この平等院修理と関連して注意しておきたいのは，道 家の祖父兼実が，建久元（1190）年に行なった平等院中 堂の修理である。兼実はこの工事のために「南都工を召 し」ている47)。したがって，すくなくともこのころから 九条家と南都工との結び付きがあったことが判る。この 南都工の実体は不明であるが，つぎに記すように為国も また南都工と呼ばれていたらしい事実がある。

(3) 東寺での造営 為国の東寺との関わりを示すのは下 記の史料 ${ }^{48)}$ である。

一, 東寺造営之南都工等事, 早任為国之例，可令勤仕公役者 也。

いつ為国が東寺の造営に関わったのか，この史料は明 らかにしないが, 文永・弘安の東寺五重塔造営以前のこ とであることはほぼ確かで, 13 世紀前半期のことと推 定できる。この時期の東寺の重要な造営事業としては, 仁治 $2(1241)$ 年前後に行われた, 灌頂院の護摩堂と七 間僧房の造営がある。

此両三年東寺修理, 三長者僧正沙汰殊被造営之, 其内灌頂堂 後立五間護摩堂, 其西立七間僧房, 是則追寛平法皇往蹤, 於 此所可有禅定殿下御入壇事, 其間依為要須, 新被造加此堂舎 成 ${ }^{49 !}$ 。

この造営は東寺三長者行遍の沙汰として行われたが，道 家の受灌頂のための造営であり，とうぜん道家側からの 援助があったはずである ${ }^{50)}$ 。為国は，この造営に関わっ たのであろう。

以上のことと東福寺仏殿とを合わせて為国が関与した ことが判明する造営を年代順に挙げると，
a. 1233 年 高野山奥院帱殿
静遍沙汰
b. 1234-35 平等院鳳凰堂修理 中原行兼奉行
c. ---1239 最勝金剛院仏殿荒立 ..........
d. 1241 頃 東寺護摩堂・僧房造営 行遍沙汰 となる。b，c は道家が施主であることの明確なもの， $\mathrm{a}, \mathrm{d}$ はかかわりが深いと推定できるものである。この ように, 為国は九条道家が関係する造営に一度ならず現 れるのである。したがって, 為国は東福寺仏殿造営のた めにとくに招かれたというよりも，道家が平生から「召 し仕う」占大工なのであったと考えるべきである。 
末光「請文案」の広定の陳述によると, 広定の論争 相手の末康は, 末光が草創の当初の大工職であったと述 べている。これにたいし，広定は当寺仏殿は物部為国が 建てたことは隠れのない事であり, 開山円爾の時代は末 広が諸造営に当たったのだとして, 末光大工職論を否定 するのである。とはいえ, 広定の論は, 末光が東福寺の 造営に関わらなかったのだと主張しているわけではな い。そもそも創立期における大工職の存在すら疑わしい のだから，広定の言い分をそのまま鵜呑みに信用するこ とはできないであろう。末光も創立当初の造営に何らか のかたちで参与していたというのが事実に近いのではな いかと思われる。

末光の出自を示すような史料はいまのところない。し かし, 同時代の同名の大工としては, 建保 7 (1219) 年 に法隆寺の舎利殿絵殿を建てた大工土佐権守平末光 ${ }^{52}$ が 浮かびあがる。舎利殿絵殿修理の願主とされる慶政上人 は先述したように, 道家の兄とも推定され, 九条家に密 接な関係をもった人物であるから, 舎利殿絵殿の大工末 光を道家の造寺のために提供したとしても不自然ではな い。むしろ, 末光はもともと九条家に結びついた大工で あった可能性すら考えられる ${ }^{531}$ 。しかし, 最勝光院仏殿 が造営された延応ころは舎利殿絵殿修理の 20 年後であ り，末光はすでに老㱓であったろうから，かりに東福寺 に参画したとしても，名目上だけであったかもしれない。

さらにすこし範囲を広げて，「末」を片字とする名の 大工を同時代の京都に求めると, まず, 高山寺において 覚厳法眼の沙汰のもとに, 嘉禄 3 (1227) 年から寛喜年 中（1229－32）に及んで三重宝塔を，また嘉禎 2（1236） 年に十三重塔を建てたのは大工末弘がいる。この高山寺 三重塔の造営は, 西園寺公経の援助下におこなわれ, 前 述したように中原行兼もその造像にかかわっている。な お, この塔は中間 8 尺, 脇間 7 尺で, 辺長が 22 尺の三 重塔としては大きな規模のものであるから，その大工は 一流の工匠であったであろう ${ }^{54)}$ 。

また, 承元 $2(1208)$ 年 5 月 15 日に焼けた法勝寺九 重塔の再建を担当した大工末包がいる。建暦 2 年のもの と推定される栄西書状 ${ }^{55}$ は, 西園寺公経がこの塔の奉行 のとき,大工は末包ひとりであったが, 栄西が奉行になっ てから工事を促進するため京工を召加えたところ, 末包 が殺傷沙汰に及んだので排除したとしている。この文脈 からすると，末包は京工ではなく，したがって多分に奈 良系の大工ということになる。末包は塔再建以前に西園 寺公経に接近していたのであろう。

このように西園寺公経の周辺には末包, 末弘といった 「末」系の番匠大工が存在したことが推定できる。そう すると道家と西園寺公経との関係, とくに造営事業に堪 能な家司を共有していたという関係からすると, 東福寺 の造営にこの「末」系の番匠大工が導入された可能性も
また認められるところであろう。この時代の奈良には 「末」系の大工が多くいる ${ }^{56}$ ので, 末包, 末弘も奈良系 の大工だったかもしれない。東大寺再建の大事業が一段 落すると, 恒常的な仕事を求めて奈良系大工が京都の貴 族の保護下に移ってくるものがあったと推定されるが, 彼らもその範疇に属すものであったのだろう。この点で は, 物部為国もその範疇にはいるであろう。仏師の慶派 が，まさに同じ時代にその活動拠点を奈良から京都に移 していることなどを視界に入れてみると，この推測も十 分成り立つのではあるまいか。

以上をもとにして，すこし大胆に考えると，すくなく とも 13 世紀前半の時点においては，九条家と西園寺家 というサークルに「召し仕」われていた大工たちの中に， 「末」を通字とした番匠大工の一派がいたとの想定がで きよう。

[第二期] 末広 ～1280 年代

「請文案」によると, 末広は鐘楼, 経蔵, 廊下, 法堂, 祖師堂, 檀那堂を建て, 円爾時代の東福寺の造営に重要 な役割を果たした。無関普門の世代に没したというから， 1280 年代まで生きていた人である。末光と末広との関 係については, 未広の聟の末康が大工職の正統性をその 家譜性にもとめて論じて，末光を当初大工職としている ことから，末光と末広は，家系的な繫がりをもっていた 可能性が濃い。末広の東福寺以外での活動は, 管見の限 りでは知られていない。末広の時代は, 無関普門その他 の来朝僧, 入宋僧が相つぎ, 本格的な禅宗と宋建築がも たらされた時期であったことは留意しておかなければな るまい。

[第三期] 定国, 定吉, 広定 1290 年代

広定の言にしたがうと, 末広が 1290 年前後のころに 没したあと, 定吉が大工職に補任され, 定吉が死ぬと定 国が大工職に補任された。広定は東福寺 4 世白雲慧暁 $(-1297.12 .25$ 寂) の世代（1292-97）に大工瞕に補任 された。末広時代の東福寺の造営は, 定吉, 定国, 広定 などの番匠が末広に従っておこなわれていた。定国と広 定は実の親子であり，また広定は末広を養父としていた。 そして定国は末広の引頭であった。末広が没する前後に 定国は, 未広の引頭として, 温室 (浴室) の造営を担当 している。広定は末広, 定吉, 定国の三代に仕えたとい うから，法堂造営も経験したであろう。東福寺の大工職 の競争者となって現れる末康は末広の聟で, おそらく老 年になった広定に替わろうとしたものであろう。末康は 徳治 2 年 (1307) から正和 4 年（1315）にかけて, 東寺 の護摩堂や大湯屋の造営および食堂払莫を行った大勧進 方大工であった人物である77?

この末康と広定との大工職争論は, 重大な意味をもつ と考えられる。この争論は, 結果的には広定の勝に州し たようである。では末広の婿であるという系譜上の有利 
さと，東寺大工職にあって技術的にも劣らないものを もっていたと思われる末康が，なぜ東福寺大工職を得ら れなかったのだろうか。そこには技術の質の問題が介在 していたのではないかと想像される。すなわち，広定は すでに東福寺にとっての建築様式となりつつあった禅宗 様に通じていたのに，末康にはそれがなかったのではな いかと思われるのである。

ともかく 13 世紀末ころの東福寺では，「定」系の大工 一族が「末」系大工に仕えるかたちで存在していたが， やがて東福寺に対する長年の実績と「末」系大工との養 父子関係の締結，そしておそらく禅宗様の習熟を梃子に して大工職を獲得するようになったと考えられる。 [第四期］広定以降 弘（広）系大工に上る独占

東福寺は 14 世紀にはいって元応元 (1319) 年に火災 にあい, 建武元 (1334）年に再び焼け，建武 3 年に仮仏 殿まで焼いてしまい，全山ほとんど灰燼に帰した。為国 から広定まで営々と建設してきた建物群は，ここにほと んど姿を消してしまった。その復興事業は建武 3 年冬に はじまり，造仏と諸堂造営の見積が大仏師院信法印と大 工左衛門尉弘光から出されている ${ }^{58)}$ 。弘光は当時の東福 寺大工職にあったと考えられるが，広定とはほぼ一世代 の開きがあるから，広定の次代または次々代の大工職之 推定できる。そして「広」は「弘」に通じるから，広定 之弘光は系譜的につながりをもつ可能性は高い。弘光以 降の東福寺大工職の継承順は

$$
\text { 弘光一 } \square \square-\text { 一弘友一弘長 }
$$

のようであったと推定され ${ }^{59)}$ ，ほぼ確実に「弘」名の大 工に独占されている。創立期以降, 為国一末広一定国と 系統が転々と移動した東福寺の大工職は, 広定より後は 広定の系統による血縁的継承形態に定着したようであ る。広定はこの「弘」系の大工家系の端緒になった人物 と考えられる。

なお,この間, 北隣に所在した十刹寺院三聖寺の大工 職は行次一対馬三郎行家一藤原行正亡「行」名の大工家 によって占有されていだ0)。

\section{5. 東福寺における禅宗様の確立とその大エ}

東福寺に遺るいくつかの中世建築遺構は，すこぶる興 味深い存在形態を示している。三門・仏殿は大仏様, 法 堂をはじめ禅堂・東司・浴室は禅宗様，六波羅門・月下 門などの門は和様という，三種類の様式の建築がある規 則性を見せながら展開しているのである。すなわち，伽 藍の中心部から周辺部にむかって, 建築の様式が大仏様 一禅宗様一和様と変化するのである。ここでいう大仏様, 禅宗粎はおおまかに分けた場合の基準としていっている のであって，三門が大仏様と禅宗様の折衷形式のもので あることは明らかだが，太田博太郎氏のいわれるよう に ${ }^{61)}$, 構造原理の面からは大仏様の範疇に属させること
ができるところであり，他もこうした基準で様式分をし ている。なお，仏殿，法堂は明治10年代まで存在してお り，その平面や構造形式は知られている ${ }^{62)}$ ので，ここで は現存するものとして加えた。

このように大仏様を中心にして，三様式が併存すると いう東福寺の建築の特徵は，東福寺の創成事情からある 程度の説明はできる。すなわち，和様を基底にもつ祖先 伝来の寺地の一画に, 道家が大仏様の建築を導入し, 実 経・円爾の時代以降に禅宗様の建築が建てられるように なったという歴史があったわけだが，それがそのまま建 築の存在形態に反映しているのである。創建時の建築が， 一度は失われたにも拘らず，なおこの特徵が持続したの は, 東福寺が五山寺院でありながら一方では摄関家の檀 寺であり続けたこと,とりわけ基幹となる建築の再建が, まだ攝関家の影響力が残っている時期に行われたことに よると考えられる。

この東福寺の建築の特徵というのは，あくまでも仮説 であって，創立期の三門・仏殿が大仏様建築であったと いう具体的な証拠は存在しない。しかし，上述した創成 期の東福寺諸大工の系統は, この三様式の存在と下のよ うによく対心もするのである。

$$
\begin{aligned}
& \text { 和様………来光………法隆寺系または三井寺系大工 } \\
& \text { 大仏様……物部為国 } \cdots \text {. 東大寺重源系の大工 } \\
& \text { 禅宗様……末広以降…東福寺大工 }
\end{aligned}
$$

いわぱ, 三様式の存在問題は, 創成期に活躍した大工た ちの系統からも説明できるのであり，三様式の存在した 可能性は高いといえる。

このように，仮説の域を出るものではないが，東福寺 における三様式の併存現象は, この寺院においては禅宗 寺院への転換と禅宗様式の採用が，その創成中途におい てなされたことと大きく関係しているとの想定を導く。 こうした仮説を踏まえ，当初の設定課題にもどって，東 福寺において禅宗様式が何時どのようにして成立したか についての私案を述べてみたい。

東福寺の建築における禅宗梯採用の時期は, 前述した ように，文永の法堂創建時である。この時期すなわち 1270 年代前半を, 東福寺での禅宗様成立の画期とする ことができる。しかしながら，この時から全面的に禅宗 様が確立したとは言い切れないものがある。

南北朝から室町時代前期を通じて, 東福寺の大工職は 「弘」名系によって独占的に世襲継承されていたが，そ れは広定に発した可能性があることは推定しておいた。 この「弘」名系の独占は，禅宗様技術の家系的なものを 軸にした継承形態の存在を思わせるが，この継承形態は また寺家側によっても支えられていたであろう。そして こうした寺家の様式選択の主体性の確立を窥わせる目安 としての修造司制度の確立は，確実には14世紀はじめこ ろであった ${ }^{63)}$ 。この東福寺大工職の世襲化と修造司制度 
の確立は，時期的にも同時性を示し，両者はほぼ表裏一 体の関係にあったことが知れる。そうした安定化の初め に位置する広定の場合は，しかし，末康との大工職相論 が物語るように，なお絶対的な安定には至っていなかっ たらしいのである。そうであれば，その前代である末広 の時代にあってはなおさらであったろう。

末広は, 道家没後, 円爾が長老之して普門寺にあり, また建仁寺の住持としてその再建にも関わっていたこ ろ，すなわち 1250 年代に活動をはじめ，鐘楼・経蔵を 建てている。川爾が一条実経によって常楽庵を与えられ， 東福寺における主導性を確立したと考えられる1270 年 前後に，法堂と祖堂・㣂堂の造営を行なっている。弘安 $3(1280)$ 年 9 月 15 日の円爾による御祈㿧等注進文 ${ }^{64}$ に は, 新㿧場所として大仏殿, 僧堂, 山門, 成就宮, 常楽 庵（閣上）なよ゙が挙げられ，これらの建物が当時存在し たことが判るが，末広の没年は 1281 年以降と考えられ るから，年譜や請文案には現れないが末広は僧堂も建て ていたと考えられる。すなわち, 法堂, 僧堂という禅宗 寺院の本質を構成する建築は, 末広を大工として建てら れたと見られる。この時の法堂, 僧掌の様式は明らかで ないものの, 再建後のものが前例にならったとすれば, 禅宗様主体のものであったと考えられる。末広の時代の 直前には鎌倉の建長寺の造営が栄僧蘭溪道隆のもとで始 まっていたし，東福寺にも文応元 $(1260)$ 年に宋僧元菴 普寧が訪れ, 弘長 2(1262) 年には無関普門が 12 年に およぶ宋での修行を終えて戻ってきていだ5!。したがっ て，この時期には禅宗建築に関する資料や知識はかなり 豊かになっていたはずであるが，末広はそれらを吸収で きる最も有利な立場にいた。

このように末広には禅宗様を京都で最初に具現した技 術者としての栄誉が与えられるが, 三門付属の鐘楼・経 蔵が大仏様であったとすれば，彼は大仏様による建築体 験から出発した大工であり，その影響からど程度抜け出 していたかに，問題がのこされている。

広定は, 自身でいうように末広の下で修行し, 法堂以 下の作事に従って，東福寺の中で確立しつつあった禅宗 様を体得した大工であった。広定が末広の養子となり， 大工職をえたのは，おそらくこの広定の禅宗様技術者と しての正統性が寺側からも認知されたからであろう。広 定の系統が, 広定以降独占継承されたのには, 大工職の 家系的継承が広く行われ始めていたという以上の理由, すなわち禅宗様を伝承しかつ指導できる家系という認知 が, 背景として存在したのではないかと思われる。その 意味では広定の方に禅宗様を定着させた大工としての評 価が与えられるべきかも知れないのである。

\section{6. 結 び}

東福寺は当初から禅寺であったのではなく, 創成期の
中途から方向転換をして禅刹になったのであった。文永 の法堂建立は, 歴史上その転換の指標となる出来事で あった。これを境にして, この寺にはその建築の様式に も変化が生じたと推定される。具体的には, 大仏様から 禅宗様への転換である。史料から推測される土王の存在 形態もそれに照応して変化したと考えられる。この転換 以前は，まだ寺院としての造営組織が形成されず，檀主 の家司層を中心とした経営組織のもとで, 檀主が召仕う 大工たちによって技術陣が構成されていた段階にあっ た。創立当初期の大工であったらしい物部為国や末光は, 東福寺創立以前から九条家に召仕われていた大工であっ たと考えられる。仏殿（おそらく三門も）をたてた大工 為国は，大仏样系の技術を継承するものであったから， これらの建築に大仏様が用いられたのは, 自然の成行き であったといえる。当然，宋様を望んだという檀主九条 道家の意向もおおきく作用したであろう。その宋様が禅 宗様でなかったのは何故かは問題として残される。禅宗 様の採用あるいは選択は，専門の禅宗道場をめざす円爾 とその弟子たち，それを支持した一条実経によってなさ れた。その造営に当ったのは末広であるが，かれはすく なくとも東福寺においての禅宗様式をはじめて試行した 工匠であったと考えられる。そして，末広時代の試行を 経て，末広が育てた工匠たちの間において，禅宗様の建 築が, 寺院側の造営組織の整備化と並行しつつ, 確立さ れてきたと推定される。広定はその中心に位置した大工 であって, 彼が確立した技術系統が正統なものと寺院側 によっても認知され(この時点では檀主側の趣向は寺院 の建築に影響を及すことはなくなっていたと考えられ る)，それによって別種の技術系統の大工の大工職競望 に打ちかち，東福寺大工職をその家系に継承させてゆく ことができた。

以上はこの論考で展開した様々の推論にもとずいた仮 説であり，本論文の結論となるものである。ここでは東 福寺だけを扱ったので，わが国の建築界において禅宗様 はいつ確立したのかといった問題までには及ぶことがで きない。しかし，この問題に東福寺は無縁ではないので， すこし私見を述べておきたい。それは東福寺と建長寺と の関わりである。鎌倉の建長寺が創建当初から確立され た禅宗様の建築で造営されていたとすれば，上に推測し たような，東福寺の禅宗様化の動きはかなり鈍重なもの であったといわざるをえない。道家その人は東福寺には 宋様を指向していたように，新しい様式に鈍感であった とは思えない。ところが，鎌倉政権とも近く，先端文化 に早く接することができる立場にいたにもかかわらず， 道家と禅宗様との明確な接点笹認めがたいのである。こ こからひきだせる推論は，確立した禅宗様の実現と採用 は，建長寺創建時期よりもつと遅れるのではないかとい

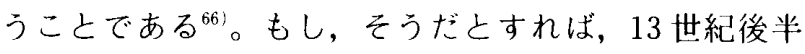


の東福寺における建築の展開は，わが国において禅宗様 が確立されてゆく過程の重要な一型を示すものに他なら ないといえるであろう。

田中淡氏は創建期東福寺の建築様式を，栄西の新様式 とともに，広義的には重源の大仏様に次ぐ第二期の中世 的新様式として規定される中間的段階とし，それはまた 中世和様内部の変化と対応している現象であるとされ $た^{67)}$ 。創建期東福寺の建築様式なるものの実態は必ずし も明らかとはいえないが，13 世紀の中葉が新様式にとつ ても中世和様によっても模索の時代であったという氏の 指摘は重要である。この小論は東福寺における, その模 索と変動の状態を，工匠史的側面からいくぶんなりとも 明らかにすることを試みたのである。

注

1）東福寺の建築と大工とを論じたものとして, 太田博太郎 『中世の建築】(彰国社, 1957 年, 五 東福寺の項, の 5日本建築史論集 III『社寺建築の研究」岩波書店, 1986 年に所収), 関口欣也『五山と禅院」(名宝日本の美術, 第 13 巻, 1983 年）がある。しかし, 大工の問題では, いずれも東大寺大工との関連を説くのみで，それ以上の 論及はなされていない。

2）東福寺の役割については，船岡誠「日本禅宗の成立」（吉 川弘文館，1987 年）を参照。

3）太田博太郎前掲書。杉山信三「藤原氏の氏寺とその院家】 (奈良文化財研究所, 学報告書第 19 冊, 昭和 43 年) 七 道家の東福寺の項。

4) 大日本古文書, 「東福寺文書之一」沙弥行恵家領処分状案。 「九条家文書一」九条道家初度処分状案。

5）「聖一国師年譜」，大日本仏教全書。

6）仲村 研,「東福寺大工関係の新史料」史林 43-2, 1960 年。 のち『中世地域史の研究」(高科書店, 1988 年) に所収。

7）惣処分の作成過程に関する検討は今後の課題である。

8）杉山前揭論文

9）沙門慶政記の「比良山霊託記」や「聖一国師年譜」。この ころ道家と禅僧との交渉はまだなかったと考えられる。

10）東福寺の名称の初出は寛元 4 年 (1246) である。すなわち, 筑後田代文書, 寛元 4 年 4 月 12 日付の六波羅下文案 (「鎌 倉遺文」 6663 号）および同年 7 月 16 日の道家の春日社 願文（『大日本史料」5-20) に「東福寺」が現れる。

11）注 10）参照。

12）「聖一国師年譜」による。円爾の普門院入寺の年月を明確 にする史料はない。普門院は覚縁が建立したものを，造 営半ばで覚縁が没したので，道家が円爾に別庵として与 えたものである。円爾とその弟子本智房（正堂俊顕とさ れる）によって完成された。室町時代末期に廃絶したが, 福山敏男氏は月下門は普門院の四足門であろうと推測し ている(「東福寺月下門」, Museum 90, 昭和 33 年。「福 山敏男著作集」三に所収)。但し円爾の「普門院造作記録」 には四足門と二宇の中門があり，中門のひとつは回廊に 付くものとして除外できるとしても，なお二つの門が月 下門の該当候補になるわけである。四足門は覚縁による もの，中門は円爾によるものである。月下門がそのどち らに当るかは, 初期東福寺の建築様式論にとって重要な
問題である。

13）土地堂・祖師堂の問題については, 関口欣也「中世禅宗 様仏堂の平面 (I) 」(日本建築学会論文報告集, 第 110 号, 1985 年) を参照。

14）仏殿と法堂の間隔は，七間半である。

15）「聖一国師年譜」

16）東福寺文書 22 円爾東福寺規式 (開山国師壁書)

17）禅院の造営組織については, 浜島一成「修造司について」, 日本建築学会大会学術講演梗概集, 1986 年。同「禅院の 造営方について」; 同 1988 年。

18）「東福寺誌】所収。

19）九条兼実置文（『鎌倉遺文】1448）

20）「兼仲卿記」建治元年 11 月 7 日条。「鎌倉遺文】12114。

21）「玉葉」文治 2 年 6 月 21 日条。

22）「明月記」天福下年 3 月 30 日条。

23）「玉葉」文治 5 年 8 月 11 日条。

24）「明月記」寬喜 2 年 5 月 25 日条。

25）「洞院搷政記」貞永元年 6 月 2 日条。

26）「葉黄記」寛元 4 年 4 月 15 日，同年 12 月 14 日条。

27）「勘仲記」建治元年 12 月 13 日条。

28）秋山光和「平等院鳳凰堂の文暦修理銘について」, 美術史 $48,1963.8$

29）「葉黄記」寛元 4 年閏 4 月 3 日条。

30）「聖一国師年譜」秋還野州受業。藤丞相道家差備仲刺吏行 笧。護衛以送。

31）「葉黄記」寬元 4 年 4 月 29 日条。

32）秋山前揭論文

33）「高山寺縁起」

34） 円爾は東福寺に定住するまで，諸寺の造営幹事を勤めて いた。

35）橋本進吉「慶政上人伝考」(「大日本仏教全書」115，遊方 伝叢書第三)

36）堀池春峰「法隆寺と西山法華山寺慶政上人」, 大和文化研 究 8-1, 昭和 38 年。

37）「古今一陽集」

38) 注 36 )。

39）「川瀬家文書」32, 東福寺領下井畠三段事。

40）【九条家文書」六, 1748-(2) 光厳院院宣案。

41）「川瀬家文書」31, 東福寺領淡路国都志郷地頭分事。

42)「奥院興廃記」

43）大河直躬【番匠」42 頁。

44）「奥院興廃記」

45）道家は承久 2 年 3 月 23 日から，法性寺において念仏法門 文の講義を静遍から受けている（玉藥，ただし思文閣本 では静通とする)。高野春秋によると静遍は，奥院造営に さいし高野平等心院に住んだとされる。この平等心院は 西南院信助(九条兼実の外叔父)によって建立されていて， 西南院の住職補任権は九条家のものであったという(和 多秀乗「高野山之重源および観阿弥陀仏」，仏教芸術 105 , 昭和 51 年 1 月)。とうぜん平等心院も九条家に関係が深 かったはずである。この平等心院居住が事実とすれば, 道家は静遍の奥院の事業を事実上助けていたことになる。 ただし，この高野春秋の説には異説もあり，事実かどう かの判断は難しい。

46) 武田五一「平等院の装飾模様に就いて」史学研究会講演集, 明治 41 年 11 月。墨書銘は大日本古文書によった。なお, 
この修理に関しては前揭秋山論文が詳しい。

47)「玉葉」建久元年 3 月 26 日条。「平等院修理即直堂, 召南 都工令直也, 僅不及一時, 須曳直了, 此間, 余凝信力念誦, 信心発起, 感応何哉, 可悦々々, 今明日, 能々調此堂事了, 来甘九日可直廻廊等, 其後又可直経蔵之由仰之。」

これについて福山敏男氏は「僅不及一時, 須曳直了」と あるから，簡単な修理工事であったとしている（福山敏 男「平等院図鑑】昭和 22 年 1 月)。しかし，そのような 些細な工事のために，兼実は一心に念誦して仏の加護を もとめたのではあるまい。事実は逆で，この工事が極め て重大な意味をもっていたからこそ，兼実は上のような 行為にでたのであろう。すなわち「曳直」とあるから, この工事は堂の位置の移動に係るものであった。おそら く前々から慎重に準備しておいてあって,この日, 一時 に満たない短時間の内に一気に堂を移動させたのであろ う。このような工事であったとしたら, 登用された南都 工の比重も小さいものではなかった筈である。「南都工を 召し」という記し方からは，この南都工と兼実との以前 からの関係のあったことを思わせるし，またそうした信 頼関係があって，兼実はこのような重大な工事を任せる ことができたのであろう。

48）実躬卿記裏文書 修理職官等申条、「鎌倉遺文】19198。

49）光明峰寺禅閤御灌頂記，「大日本史料」5-13。

50）本朝高僧伝 54 によると, 行遍は延応元年に道家三子家実 の病を尊勝法の祈㿧を行って治瘾させており,この功績 から道家の信任が厚かったものと思われる。

51）「承久記」に，土御門院に「召し仕はれける番匠一人」が 院の流刑に御供したと記すように，主従関係をもった「召 し仕う」番匠の存在は,この時代広く見られた。

52）法隆寺東院舎利殿及び絵殿棟札。「古今一陽集」。

53) 慶政は嘉禄二年 (1226) に法華山寺縁起 (図書寮叢刊「諸 寺縁起集」所収）を草している。また慶政は九条道家に 頼んで四条上皇（道家の娘藻壁門院の子）の清涼殿を譲 り受け，独力で三井寺に移している(三井寺興乗院等事)。 この移築は, 仁治 3 年 (1242) の四条上皇の逝去後であ るはずだから，道家の東福寺創建とほぼ時を同じくして いる。こうした道家と慶政との慗がりや，両者の造寺活 動の同時性からみても, 両者間に共通する建築工匠の存 在を想定することは，けっして不当なことではなかろう。

54）【高山寺縁起」の造営記事は大工のことまで記していない のであるが, 十三重塔と三重宝塔の大工末弘に限って挙
げているのは，末弘がとくに高名な大工であったか，ほ んらい高山寺に属さず, 有力者から派遣された大工であっ たからであろう。

55）田中 稔氏が紹介された建暦二年と推定される栄西書状 (同氏「覚遍本明本抄および紙背文書」,「奈良国立文化 財研究所年報 1960」。鎌倉遺文」に 1869 文書として所収)

56）大河直躬「大工職についての覚書」(「建築史研究」27号) 付載の「大和番匠一覧（鎌倉時代の部)」参照。

57）末康は「東宝記」に東寺の護摩堂造営（1307）の大勧進 大工, 大湯屋造営 (1315), 食堂払真 (1317) の大工とし て現われる。末康がどこに属していたかは明確ではない が, 当時の大勧進は泉涌寺の素道上人であり, 泉涌寺工 であった可能性はある。

58）「東福寺誌。太田前掲論文。

59) 拙稿「東福寺大工の系譜について」, 日本建築学会大会学 術講演梗概集, 1989 年 10 月。

60) 仲村研前揭論文。注 60)。

61) 太田前揭論文。

62）太田前揭論文。また，筆者は近時，東京国立博物館にお いて, 江戸時代の東福寺の仏殿 · 三門 - 法堂 - 僧堂の木 口図と建地割図に接したが, それらは仏殿・三門を大仏 系様, 法堂・僧堂を禅宗系椂としている。これらの図に ついては機会を見て紹介したい。

63）注 17）参照。

64）慧日諸軸文書 (「東福寺誌」所収)。

65）「東福寺誌。大宋諸山図とこうした宋僧や入宋僧との関 係については注 1) の関口論文参照。

66) 関口氏は禅宗様式を 13 世紀から 14 世紀半ころの中国五 山建築の様式に対応するものとするとされた(前揭論文)。 これからすると，建長ころ，すなわち 13 世紀前半期にす でに完全な禅宗様式の建築が鎌倉に建っていたとする論 は容易には出せないだろう。建長寺が当初から専門禅宗 道場であったとしても，その建築が禅宗様であったとい う保証はないのである。

67) 中世新様式の出現とその時期（太田博太郎博士還暦記念 論文集『日本建築の特質」, 中央公論美術出版, 1976 年), の5田中淡『中国建築史の研究」, 弘文堂, 1989 年に 所収。

(1991 年6月 10 日原稿受理, 1991 年 11 月 12 日採用決定) 